\title{
Karol DABROWSKI
}

Lublin

\section{Innowacyjność izb gospodarczych na tle modernizacyjnej funkcji prawa}

$\mathbf{N}$ iniejszy artykuł omawia aspekt styku trzech zjawisk: innowacyjności, samorządu gospodarczego oraz prawa w jego modernizacyjnej funkcji. Innowacyjność stała się bowiem tematem modnym w ostatnich czasach. Mówi się o innowacyjnej gospodarce, gospodarce opartej na wiedzy itp. Nauka lubi neologizmy, którymi opisuje nowo-występujące zjawiska, nowo-odkryte, bądź na nowo opisane. Wraz ze zmianą oblicza nauki, nowe słowa zastępują te, które wyszły z mody. Przykładowo, nikt już nie mówi o popularnej w I połowie XX wieku psychotechnice; pedagogika pracy broniona przez koryfeuszy tej dyscypliny waha się między filozofią pracy a doradztwem zawodowym, a w jej miejsce pojawia się psychopedagogika pracy ${ }^{1}$. Zaś cybernetyka i prakseologia kojarzą się z okresem PRL. Po 1989 roku upowszechniły się słowa „dyskurs” i „dewolucja”, funkcjonujące obok ,dialogu” i „decentralizacji”2. Nie używa się natomiast słów „postępowy”, „wsteczny”, „sztandarowy” i „burżuazja”. Język „,innowatorów” zafascynowanych procesami innowacji byłby więc wdzięcznym obiektem zainteresowań filologów ${ }^{3}$.

Jednakże - w przypadku samorządu gospodarczego - za zmianą nazewnictwa nie idą zmiany systemowe. Izby gospodarcze - zwane teraz ,instytucjami otoczenia biznesu” - jak nie były po 1989 roku samorządem gospodarczym, tak do tej pory nie są; ustawodawstwo ich dotyczące nie spełnia swej modernizacyjnej funkcji; a one nie mogą w pełni odegrać roli ośrodków wspierania innowacji w polskiej gospodarce ${ }^{4}$.

Pojęcie „modernizacji” często jest używane w literaturze humanistycznej. Można mówić o modernizacji prawa, wymiaru sprawiedliwości, administracji publicznej czy wręcz całego społeczeństwa ${ }^{5}$.

${ }^{1}$ Por. J. E. Karney, Psychopedagogika pracy. Wybrane zagadnienia z psychologii i pedagogiki pracy, Warszawa 2007, s. 16; P. Macewicz, Kryzys psychotechniki, Warszawa 1937, s. 3; H. Münsterberg, Grundzüge der Psychotechnik, Lipsk 1928, s. 1; T. W. Nowacki, Pedagogika pracy jako dyscyplina pedagogiczna, „Pedagogika Pracy” 1975, z. 1, s. 11; R. Parzęcki, Potrzeby i propozycje badań w obszarze poradnictwa zawodowego, w: Pedagogika pracy w perspektywie dyskursu i przyszłości, red. R. Gerlach, Bydgoszcz 2010, s. 165; Z. Wiatrowski, Podstawy pedagogiki pracy, Bydgoszcz 2005, s. 61.

${ }^{2}$ H. Izdebski, Fundamenty współczesnych państw, Warszawa 2007, passim.

${ }^{3}$ Por. K. Ożóg, Nowe czasy - nowy język polski, ,Gazeta Uniwersytecka Pracowników i Studentów Uniwersytetu Rzeszowskiego" 2004, nr 7, s. 4.

${ }^{4}$ Por. R. Kmieciak, S. Wykrętowicz, Ustrój prawny izb gospodarczych w Polsce w przeszłości i obecnie. Działania zbiorowe - teoria i praktyka, red. A. Matysiak, „Prace Naukowe Akademii Ekonomicznej im. O. Langego we Wrocławiu" nr 985, Wrocław 2003, s. 111.

${ }^{5}$ Por. J. Urbanovic, Rozwój akademickich programów kierunku administracji publicznej na Litwie w kontekście modernizacji administracji publicznej, „Administracja publiczna. Studia krajowe i międzynarodowe” 2009, nr 1, s. 103; W. Witkowski, Uwagi o modernizacji sq̨ów i prawa na ziemiach polskich w czasach zaborów, w: Państwo - prawo-myśl prawnicza. Prace dedykowane profesorowi Grzegorzowi Leopoldowi Seidlerowi w dziewięćdziesiata rocznice urodzin, Lublin 2003, s. 301. 
Modernizacja (z języka francuskiego moderne - nowoczesny) posiada wiele „twarzy”. Wiąże się z unowocześnieniem, usprawnieniem, racjonalizacją, rozwojem technicznym, dostosowaniem do zmienionej rzeczywistości („uwspółcześnieniem”) i wreszcie ulepszeniem . Posiada więc wydźwięk pozytywny, zakłada aktywność podmiotu „modernizującego” siebie, innych lub swoje otoczenie. Wiąże się ze zmianą społeczną, sympatią do zmian i wreszcie - nastawieniem innowacyjnym ${ }^{7}$.

W klasycznym - słownikowym ujęciu ,innowacja”, to z łaciny innovatio-wprowadzenie czegoś nowego i zarazem rzecz nowo wprowadzona ${ }^{8}$. Już więc ten sposób definiowania innowacji kładzie nacisk na jej dwa aspekty: procesowy i rzeczowy. Innowacja może być bowiem procesem (postępowaniem, działaniem), jak też obiektem (elementem, rzeczą, przedmiotem materialnym i niematerialnym, pomysłem, ideą, koncepcją). Jak stwierdził niemiecki autor Eduard Heindl: Innovation is an idea in action ${ }^{9}$.

Wspólnym mianownikiem obu tych aspektów jest zmiana. Zmiana ta zachodzi w zastanej rzeczywistości, zmieniając ją na lepsze. „Na lepsze”, ponieważ innowacja niesie za sobą wydźwięk pozytywny. Co do zasady nie ma (lub też nie powinno być) „innowacji negatywnych”. Moga być innowacje o późniejszych negatywnych skutkach społecznych. Energia atomowa będzie tego chyba dobrym przykładem. Jednak nawet to, co na pierwszy rzut oka wydaje się być li tylko zagrożeniem, może znaleźć pożyteczne zastosowanie - i odwrotnie przydatne wynalazki mogą nieść zgubę człowiekowi i środowisku naturalnemu.

Współcześnie - jak podali Grażyna Niedbalska i Edward Stawasz - ,innowację” i ,innowacyjność" definiuje się zgodnie z międzynarodowym podręcznikiem Oslo Manual, zalecanym do statystycznych badań nad innowacyjnością. Pod pojęciem ,innowacji” rozumie się więc wdrożenie nowego lub istotnie ulepszonego produktu (wyrobu lub usługi), nowego lub istotnie ulepszonego procesu, nowej metody marketingu lub nowej metody organizacji w zakresie praktyk biznesowych, organizacji miejsca pracy bąź relacji ze środowiskiem zewnętrznym lub też - ściślej - nowe lub istotnie ulepszone produkty i procesy ${ }^{10}$.

Produkty to mogą być gotowe wyroby, jak też usługi (np. bankowe). Zaś procesy i metody mogą być techniczne, organizacyjne, jak i marketingowe. Co istotne, aby można było uznać dane produkty i procesy za innowacyjne (lub też, innowacje” same w sobie), to wystarczy, że są nowe lub istotnie ulepszone już z punktu widzenia wdrażającego je podmiotu ${ }^{11}$.

W ekonomii pojęcie innowacji rozpropagował Joseph Alois Schumpeter (1883-1950), jeden z najbardziej znanych ekonomistów XX wieku. Był autorem teorii wzrostu gospodarczego i cyklów koniunkturalnych wywoływanych przez przełomowe innowacje (zwane też „kombinacjami”). Interesował się procesami zachodzącymi wewnątrz systemu kapitalistycznego, który nazywał „twórczą destrukcją”. W swych pracach odwoływał się do przykładów, nie gardząc subiektywnymi teoriami filozoficznymi i historiozofią. Pisał o pojęciu i znaczeniu innowacji, dyfuzji innowacji (tzw. „Diffusionstheorie”), triadzie innowacji, fazach procesu

\footnotetext{
${ }^{6}$ Por. Stownik wyrazów obcych PWN, Warszawa 1980, s. 484.

7 Por. T. Kizwalter, ,Nowatorstwo i rutyny”. Społeczeństwo Królestwa Polskiego wobec procesów modernizacji (1840-1863), Warszawa 1991, s. 8.

${ }^{8}$ Por. Stownik wyrazów obcych PWN, op. cit., s. 307.

${ }^{9}$ E. Heindl, Was ist eine Innovation?, materiał Hochschule Furtwangen, 2008, http://webuser.hs-furtwangen.de/ (dostęp 25.04.2011)

${ }^{10}$ G. Niedbalska, E. Stawasz, Innowacje, http://www.parp2.mpcms.pl/parp/data/slownik/slownik.html - dalej jako Słownik PARP (dostęp 4.08.2011). Por. też J. Baruk, Istota innowacji i ich wpływ na rozwój podmiotów gospodarczych, publikacja w bazie PITWIN, http://www.pitwin.edu.pl/.

${ }^{11}$ Ibidem.
} 
innowacyjnego oraz roli przedsiębiorców w nim. Analizując cykle koniunkturalne odwoływał się do koncepcji Nikołaja Kondratjewa, Clementa Juglara i Josepha Kitchina ${ }^{12}$.

Napisał m.in. Teorię rozwoju gospodarczego (Theorie der wirtschaftlichen Entwicklung 1911 i 1926); Kryzys państwa podatków (1918); Socjologię imperializmu (Zur Soziologie der Imperialismen 1919); Cykle koniunkturalne (Business Cycles 1939, wyd. niemieckie Konjunkturzyklen 1961); Kapitalizm, socjalizm, demokracja (Capitalism, Socialism, and Democracy 1942; Kapitalismus, Sozialismus und Demokratie 1950) ${ }^{13}$. Kilka lat temu ukazało się zresztą wydanie esejów Schumpetera, przygotowane przez Instytutu Misesa ${ }^{14}$.

Schumpeter rozumiał innowacje, jako:

1) wprowadzenie do produkcji nowych towarów lub też udoskonalenie dotychczas istniejących;

2) wprowadzenie nowej lub udoskonalonej metody produkcji;

3) otwarcie nowego rynku;

4) znalezienie nowych źródeł surowców lub półfabrykatów;

5) wprowadzenie nowej organizacji produkcji lub sprzedaży ${ }^{15}$.

Jego zdaniem innowacje polegały na tworzeniu zmian fundamentalnych lub radykalnych, obejmujących przekształcenie nowej idei lub technologicznego wynalazku w rynkowy produkt lub proces. Natomiast upowszechnianie innowacji stanowiło - jego zdaniem - odrębny rodzaj zmian, które określał mianem imitacji. Oznaczało to, iż innowacja stanowiła każdorazowo zmianę niepowtarzalną (jednorazową, nieciągłą), natomiast zmiany o charakterze imitacyjnym lub inwencyjnym miały ciagły, powtarzalny przebieg ${ }^{16}$.

Podkreślenie ,jednorazowości” innowacji oraz ,powtarzalności” procesu innowacyjnego ma szczególnie istotne znaczenie. Pozwala bowiem na zbadanie, czy istnieją elementy wspólne wszystkim (bądź większości) procesów innowacyjnych bez względu na rodzaj wprowadzanej innowacji. Proces innowacyjny modelowo przechodzi kilka faz:

1) potrzeba,

2) pomysł,

3) projekt,

4) produkt,

5) rynkowe wdrożenie łącznie ze sprzedażą ${ }^{17}$.

Pamiętać jednak należy o tym, iż innowacja technologiczna nie musi iść w parze z poziomem rozwoju gospodarczego. Jak bowiem pisał Schumpeter, metody gorsze pod względem technicznym moga jednak być najodpowiedniejsze $w$ danych warunkach ekonomicznych ${ }^{18}$.

\footnotetext{
${ }^{12}$ Por. E. Borbely, J. A. Schumpeter und die Innovationsforschung, MEB 2008m, 6th International Conference on Management, Enterprise and Benchmarking, 30-31 May 2008 Budapest, Hungary.

${ }^{13} \mathrm{http}: / /$ pl.wikipedia.org/wiki/Joseph_Schumpeter; http://de.wikipedia.org/wiki/Joseph_Schumpeter (dostęp 25.04.2011).

${ }^{14}$ J. A. Schumpeter, Imperialism and social classes, wstęp B. Hoselitz, przeł. H. Norden, Auburn 2007. Tam też zwięzły biogram Schumpetera podany przez Hoselitza (s. V). Publicystyczną biografię Schumpetera napisał T. K. McGraw, Prophet of innovation: Joseph Schumpeter and creative destruction, Harvard University Press 2007. Por. też A. Heertje, J. Middendorp, Schumpeter on the economics of innovation and the development of capitalism, Edward Elgar Publishing 2006, s. 3.

15 J. Schumpeter, Teoria rozwoju gospodarczego, wstęp J. Górski, przeł. J. Grzywicka, Warszawa 1960, s. 104.

${ }^{16}$ Por. G. Niedbalska, E. Stawasz, Innowacje, op. cit. oraz M. Keklik, Schumpeter, innovation and growth: long-cycle dynamics in the post-WWII American manufacturing industries, Ashgate Publishing, Ltd. 2003, s. 9 (tam o wzorcach innowacji).

${ }^{17}$ Por. M. Urbaniak, Podstawowe pojęcia i interpretacje dotyczace innowacji, procesu innowacyjnego oraz systemu innowacji, s. 12 (www.innowacyjna-wielkopolska.pl).

${ }^{18}$ J. Schumpeter, Teoria rozwoju..., s. 21.
} 
Innowacyjność - jak podał Piotr Niedzielski - jest cecha podmiotów gospodarczych lub gospodarek, oznaczajaca zdolność do tworzenia i wdrażania innowacji, jak również ich absorpcji ${ }^{19}$. Wiąże się z aktywnym angażowaniem się w procesy innowacyjne. Oznacza również zaangażowanie w zdobywanie zasobów i umiejętności niezbędnych do uczestniczenia w tych procesach. Bywa mierzona ilością tworzonych i wdrażanych innowacji oraz nakładami przeznaczanymi przez przedsiębiorstwa na działania w tym zakresie. Wiąże się z posiadanymi zasobami (ludzkimi, rzeczowymi, kapitałowymi, informacyjnymi), ale także umiejętnością ich wykorzystania, czyli czymś co jest zwane „dojrzałością innowacyjną”. Dojrzałość innowacyjna to albowiem odpowiedni poziom kultury organizacyjnej, warunkujacy wykorzystanie przedsiębiorczości, innowacyjności, kreatywności oraz innych zdolności do tworzenia, absorbowania i wprowadzania innowacji w różnych dziedzinach ${ }^{20}$. Dojrzałość innowacyjna może być ponadto traktowana jako specyficzny zasób dla podmiotów gospodarczych, będacy swoista kompilacja prostszych zasobów o charakterze materialnym (np. środki finansowe, warunki do pracy) i niematerialnym (np. umiejętności, zdolności) ${ }^{21}$.

Innowacyjność jest określana przez kompetencję innowacyjną (kolejny osobliwy termin ze „słownika innowatorów”), która charakteryzuje właściwości jednostki, warunkujące jej postawę w procesie zmiany. Kompetencja innowacyjna jest silnie skorelowana z plastycznością innowacyjną (zdolnością, skłonnością i łatwością do poddawania się procesom innowacyjnym) oraz umiejętnością uczenia się. Im wyższa jest bowiem kompetencja innowacyjna, tym lepsze przystosowanie wykazuje jednostka w zakresie uczenia się i tym wyższą plastycznością się charakteryzuje. Wiedza zdobywana w procesie uczenia się wspomaga wprowadzanie zmian $w$ organizacji, co z kolei powoduje zdobywanie nowej wiedzy, która wyzwala kolejne potrzeby. Twórcze napięcie, towarzyszace procesom uczenia się, pobudza potrzebe pogtębiania umiejętności teoretycznych i praktycznych (kompetencji) do zarzadzania innowacjami. W procesie uczenia się ksztattuja się także postawy, warunkujace tworzenie zachowań innowacyjnych. Wykorzystanie możliwości uczenia się w organizacji pozwala wypracować postawy proinnowacyjne, nastawione na inicjowanie, kreowanie $i$ wdrażanie zmian, a przez to podniesienie efektywności ekonomicznej jej działalności ${ }^{22}$.

O innowacyjności jednostki decyduje także motywacja innowacyjna. Definiowana jest jako mechanizm akceptowania nowości, generujacy postawe jednostki wobec innowacji $i^{23}$. Jak to celnie ujął Piotr Niedzielski, motywacja do wprowadzania innowacji $w$ dużej mierze wynika z radości robienia czegoś, co nigdy dotad nie zostało zrobione. Do czynników generujących innowacyjność jednostki zaliczył on również zdolność innowacyjną. Jest to cecha jednostki, która określa jej wewnętrzne i nabyte predyspozycje do tworzenia, implementowania i adaptacji innowacji z otoczenia, ale także jej podatność na wpływ czynników zewnętrznych, warunkujących takie zachowania ${ }^{24}$.

Przy omawianiu innowacyjności mówi się także o ,potencjale innowacyjnym”. Rozumie się go, jako zdolność podmiotu do opracowywania, wdrażania oraz rozpowszechniania innowacji. Potencjał innowacyjny danego podmiotu tworzy jego personel oraz warunki wewnętrzne i zewnętrzne, w jakich funkcjonuje. Otoczenie to również może być, zdaniem badaczy,

\footnotetext{
${ }^{19}$ P. Niedzielski, Innowacyjność, w: Stownik PARP.

${ }^{20}$ Ibidem.

${ }^{21}$ Ibidem.

${ }^{22}$ Ibidem.

${ }^{23}$ Ibidem

${ }^{24}$ Ibidem.
} 
pro- lub antyinnowacyjne. Stąd też znaczny wpływ na działania innowacyjne mają interesariusze (stakeholders) podmiotu zainteresowanego innowacjami. Mogą się do nich zaliczać urzędnicy, przedsiębiorcy, pracownicy, konsumenci itp.

Dlatego też wprowadzono pojęcie innowacyjnego środowiska przedsiębiorczości (milieu enterpreneurial innovante). Znanym propagatorem tej koncepcji był francuski badacz Philippe Aydalot, który w latach osiemdziesiatych XXw. próbowat określić warunki zewnętrzne, konieczne dla powstawania przedsiębiorstw i ich zdolności do innowacji ${ }^{25}$. Aydalot negował tą koncepcję postępu technicznego, według której innowację określają parametry techniczne, stosowane wszędzie w ten sam sposób. Innowacja, jego zdaniem, jest powiązana z lokalnym środowiskiem przedsiębiorczości; jest owocem innowacyjności tego środowiska i odpowiada potrzebom rozwoju lokalnego. Ten tok myślenia doprowadził Aydalota do skrajnego stwierdzenia, iż źródłem innowacji nie jest przedsiębiorstwo, lecz środowisko, w którym ono działa $^{26}$.

Takie ujęcie tematu wydaje się zbyt wąskie czy wręcz jednostronne. Zdarzają się innowacje powstałe w warunkach wybitnie niesprzyjających budzeniu innowacyjności, a ponadto czasem środowisko - jakby się wydawało - stworzone do ,produkowania” innowacji, takiego wyniku nie daje. Teza powyższa łatwo jest więc falsyfikowalna. $\mathrm{W}$ dodatku bywa tak, iż w przypadku przedsiębiorstw to kryzys na rynku wymusza innowacyjność, a prosperita ją usypia $^{27}$.

Mimo wszystko nie można w rozważaniach na temat innowacyjności, pomijać roli tegoż środowiska. Innowacyjne środowisko przedsiębiorczości postrzega się jako zbiór zjawisk mających swój określony wymiar przestrzenny. Ta przestrzeń nie musi być ściśle zakreślona i tak naprawdę nie da się tego uczynić. Jest to niemożliwe, ponieważ krążenie innowacji w dobie globalizacji przełamuje ciasne ramy regionalne. Nie można też negować wypadków powstania innowacji na wyizolowanym terenie w umyśle samorodnego wynalazcy ${ }^{28}$.

Jak podała Aleksandra Jewtuchowicz, środowisko grupuje system produkcji, kulturę techniczna i jednostki ekonomiczne. Spójność tlumaczy się poprzez wyraźnie zdefiniowane i specyficzne dla tego zbioru zachowania. Posiada on kulturę techniczna, wiedze, swoje normy $i$ wartości zwiqzane z działalnościq ekonomiczna. Te różnorodne elementy generuja określone, dajace się skodyfikować zachowania, wynikajace z reguł wewnętrznej organizacji i mechanizmów regulacji. Przedsiębiorczość, organizacja, zachowania przedsiębiorstw, sposób stosowania techniki, zrozumienie regut rynku i umiejętności sa jednocześnie integralnymi czynnikami sktadajacymi się na środowisko i stanowiq uwarunkowania kierujace zachowaniami aktorów i relacjami, które oni utrzymuja ${ }^{29}$.

Obszar geograficzny, o którym była mowa mimo braku fizycznych granic charakteryzuje się tym, iż „reprezentuje pewną jedność wyrażającą się w identyfikowalnych i specyficznych zachowaniach" "30. Staje się więc, nie tyle obszarem fizycznym, ale obszarem „społecznym”, może nawet „moralnym”, ale zarazem ,wirtualnym” - skoro tak wiele dzieje się w sieci.

\footnotetext{
${ }^{25}$ A. Jewtuchowicz, Innowacyjne środowisko przedsiębiorczości, w: Słownik PARP.

26 Ibidem.

${ }^{27}$ Por. A. Dąbkowski, Innowacyjne strategie przedsiębiorstw w latach kryzysu 2007-2012, publikacja w bazie PITWIN.

${ }^{28}$ Por. P. Zbierowski, Potencjat innowacyjny $i$ wysoka efektywność regionu i przedsiębiorstw, materiały XIV Konferencji Komputerowo Zintegrowane Zarządzanie, Zakopane 9-12.01.2011, s. 607.

${ }^{29}$ A. Jewtuchowicz, Innowacyjne środowisko przedsiębiorczości, op. cit.

${ }^{30}$ Ibidem.
} 
W przypadku izb gospodarczych owszem można powiedzieć o innowacyjności, gdy wprowadzają nowe usługi dla przedsiębiorców, czy unowocześniają swój system informatyczny. Jednak to nie wystarcza. Modelowo przedsiębiorca potrzebuje funduszy na realizację swojego pomysłu oraz instytucji, która oceni jego projekt pod kątem opłacalności, pomoże ułożyć biznesplan i będzie kredytować jego działalność. Projekty innowacyjne mogą bowiem iść dwutorowo:

1) gdy naukowiec tworzy innowację i szuka przedsiębiorcy, który chciałby ją rynkowo wdrożyć (tzw. model ,push”);

2) gdy przedsiębiorca zgłasza zapotrzebowanie na innowację i szuka naukowca, który pomoże mu rozwiązać problem (tzw. model „pull”).

W ramach modelu „pull” propagowane jest podejście „ssania innowacji” (innovation pull), w którym innowacje powstają w odpowiedzi na zapotrzebowanie przedsiębiorców i ich klientów (konsumentów, kontrahentów, zleceniodawców itp.). Różni się ono od typowego modelu transferu innowacji ze sfery naukowo-badawczej do gospodarki, opartego na podejściu ,tłoczenia innowacji” (innovation push), które zakłada szukanie rynkowych zastosowań dla wyników prac badawczych dopiero po ich zakończeniu. Model ,pull” jest więc korzystniejszy dla obu stron procesu innowacyjnego ${ }^{31}$.

Innowacyjna działalność izb gospodarczych nie może zatem ograniczać się do kilkukrotnych szkoleń, przeliczanego na godziny doradztwa, konferencji otwierającej i zamykającej projekt oraz założenia na krótki czas portalu w stylu „Naszej Klasy” dla uczestników projektu. Niestety często tego typu metoda działania jest wymuszana przez sposób realizacji projektów unijnych w Polsce.

Problemem może być finansowanie innowacyjnych projektów badawczych, co do których nie ma pewności, czy zakończą się one sukcesem. Placówka badawcza, żeby znaleźć odpowiedź na problem zgłoszony przez przedsiębiorcę musi bowiem wypróbować różne drogi prowadzące do celu. Musi więc w projektach innowacyjnych istnieć możliwość modyfikacji, zmiany, a nawet porzucenia danego programu. Tak zresztą, jak w koncepcji naukowych programów badawczych Imre Lakatosa.

W ujęciu Lakatosa historia nauki staje się historią naukowych programów badawczych. Program badawczy, jako zbiór teorii, może być oceniany z punktu widzenia jego postępowości. Może też zostać uznany za fałszywy, gdy zostanie zaprzeczony przez fakty. Stanie się natomiast postępowy, gdy kolejne doświadczenia potwierdzą jego słuszność. Program badawczy może być więc postępowy lub degenerować, zależnie od wyników prowadzonych badań. Lakatos barwnie pisał o „rdzeniu” programu badawczego i jego „pasie ochronnym”. Rdzeń programu można porównywać do wiedzy zastanej, która tworzy co do zasady „nieobalalny" dogmat danego programu. Dlatego też - wedle koncepcji Lakatosa - należy podtrzymywać te fragmenty wiedzy zastanej, które służą jako rdzeń postępowego programu badawczego; zaś rewidować te, które wchodzą w skład rdzenia programu degenerującego się. Zaś na ,pas ochronny" składają się hipotezy potwierdzające teorię leżącą u podnóża programu i tworzącą jego rdzeń. Mogą być one dowolnie modyfikowane przez badaczy, po to właśnie by sprawdzić, czy aby dany program jest nadal prawidłowy. Porzucenie lub przekształcenie rdzenia będzie więc równoznaczne z porzuceniem programu badawczego na rzecz innego, konkurencyjnego, lepszego programu ${ }^{32}$.

\footnotetext{
${ }^{31}$ Por. J. Kosiec, Realizacja projektu SPIN - ZADANIA, http://www.spin.fren.org.pl/index.php?option=com_content\&view $=$ article \&id=8\&Itemid=7 (dostęp 4.08.2011).

${ }^{32}$ Por. I. Lakatos, Pisma z filozofii nauk empirycznych, przeł. W. Sady, Warszawa 1995, s. 71.
} 
Dzięki koncepcji Lakatosa nie musimy martwić się, że uczeni prowadzą badania nad wzajemnie wykluczającymi się teoriami. Nie wiemy bowiem, który program badawczy w przyszłości się rozwinie (stanie się postępowy), a który upadnie (zdegeneruje). Dopuszczamy więc równoległe rozwijanie konkurencyjnych ze sobą programów badawczych, ponieważ może się zdarzyć, iż na początku wszystkie będą postępowe (niosły ze sobą nowe metody, wyznaczały różne kierunki badań, służyły do przeprowadzenia nowatorskich eksperymentów itp.) Nie należy więc na wstępie rozpoczynanych badań dokonywać wyboru programu. Można nawet poczekać, aż niektóre programy zaczną się degenerować. Co więcej, nie należy przedwcześnie porzucać programów degenerujących się. Może się bowiem okazać, iż program degeneruje się nie z powodu błędnych założeń tworzących jego rdzeń, lecz z powodu zbyt małej pomysłowości badaczy w niego zaangażowanych, subiektywnego konfliktu między naukowymi koteriami lub niskiego poziomu techniki na danym poziomie cywilizacyjnym. Wnioski wyciagnięte podczas obserwacji upadku programu badawczego mogą być bowiem przydatne do oceny programów pozostałych. Zaś konkurencja programów badawczych prowadzi do rozwoju nauki ${ }^{33}$.

Ratunkiem dla innowacyjnej działalności izb gospodarczych powinny być inkubatory technologiczne. Jednak nie mogą być to biura, jedynie oferujące wynajem pomieszczeń za nieco niższy czynsz przez okres pół roku, przyjmowanie korespondencji (którą i tak przynosi listonosz), użyczanie sali konferencyjnej na 5 godzin miesięcznie, komputera na 2 godziny miesięcznie, sprzątania chodników i parkingu (co i tak jest obowiązkiem właściciela budyn$\mathrm{ku}$ ) oraz odpłatnego udostępniania xera, faxu, sprzętu biurowego; gdyż taki ,inkubator” to każdy początkujący przedsiębiorca może sobie założyć we własnym domu przy pomocy rodziny $i$ do tego wcale nie potrzebuje projektu unijnego za miliony złotych ${ }^{34}$. Tego typu instytucje z innowacyjnością łączy - jak to napisał Jan Kaźmierczak - jedynie nazwa ${ }^{35}$.

Prawdziwy inkubator innowacyjności winien być, jak to się mówi w żargonie doktoranckim „labsem”, „tyglem innowacji”, w którym przedsiębiorcy-naukowcy nie musieliby się liczyć z kosztami odległości geograficznej; a ferment umysłowy, „burza mózgów”, wzajemne kontakty wzmagają ,produkcję” innowacji. W tak twórczej instytucji byłaby szansa (mimo, iż prezentowana wizja jest mocno utopijna) przekroczenia ograniczeń wynikających ze zwykłej konkurencji, rozważania problemów technologicznych, tworzenia repozytoriów wiedzy, wzajemnego uczenia się i poszukiwania wspólnych rozwiązań. Albowiem cechą skupionego wokół inkubatora środowiska innowacyjnego jest nie tylko umiejętność do generowania informacji, ale i „wyłapywania” jej z zewnątrz - ze świata zewnętrznego (najlepiej łącznie z zasobami tak, aby za niematerialną informacją szły jak najbardziej materialne fundusze). Taki inkubator mógłby nawet w pewnym momencie wytworzyć własną kulturę pracy i współpracy, przy specjalizacji uczestniczących w nim podmiotów; a co za tym idzie - przewagę konkurencyjną wśród innych podmiotów rynkowych ${ }^{36}$.

\footnotetext{
${ }^{33}$ Por. A. Grobler, Metodologia nauk, Kraków 2006, s. 81.

${ }^{34}$ Por. Regulamin wewnętrzny inkubatora przedsiębiorczości Fundacji Puławskie Centrum Przedsiębiorczości, http://www.fpcp.org.pl/inkubator_przedsiebiorczosci1.html (dostęp 4.08.2011).

${ }^{35}$ Por. J. Kaźmierczak, Inżynieria innowacji: techniczny wymiar wdrażania innowacyjnych rozwiazań w gospodarce, materiały XIV Konferencji..., s. 466.

${ }^{36}$ Por. np. M. Huczek, Parki naukowo-technologiczne a rozwój małych i średnich przedsiębiorstw, ,Zarządzanie i Marketing. Zeszyty Naukowe Wyższej Szkoły Humanitas”2007, nr 1, s. 47; K. Klincewicz, Polska innowacyjność. Analiza bibliometryczna, Warszawa 2008, s. 5; A. Tórz-Rzepczyńska, Wybrane problemy oceny efektywności działania inkubatora technologicznego, ,SOOIPP Annual 2008”, s. 241.
} 
Dla efektywnej współpracy $\mathrm{B}+\mathrm{R}$ istotne jest również wsparcie przy przebrnięciu przez formalności patentowe i związane $\mathrm{z}$ tym opłaty. Postępowanie przed Urzędem Patentowym - mimo wielu uprzystępniających ją publikacji - może wydawać się nieco skomplikowane, a opłaty zbyt wysokie. Pomoc ze strony izb, prowadzących taki inkubator, byłaby więc wielce pożądana $^{37}$.

Nie ulega wątpliwości, że innowacyjna działalność izb gospodarczych przełożyłaby się na poziom innowacyjności kraju, liczony wedle skali przyjętej w Innovation Union Scoreboard 2010, nawet jeśli mielibyśmy zastrzeżenia co do jego metodologii ${ }^{38}$.

Należy jednak podkreślić, iż obecne izby gospodarcze, funkcjonujące na podstawie ustawy z 30 maja 1989 roku $^{39}$, nie są instytucjami samorządu gospodarczego i gdyby nie zagospodarowywane przez nie fundusze unijne, to nie odgrywałyby praktycznie żadnej roli w polskiej gospodarce. Dzieje się tak, wbrew deklaracji ustawodawcy zawartej w art. 2 tego aktu prawnego: Izba gospodarcza jest organizacja samorzadu gospodarczego, reprezentujaca interesy gospodarcze zrzeszonych w niej przedsiębiorców, w szczególności wobec organów władzy publicznej.

Wypada bowiem odróżniać pojęcie „samorządu” od „wspólnoty samorządowej”; mając oczywiście świadomość, iż pojęciem „samorządu” określa się zarówno:

a) samodzielne zarządzanie sprawami publicznymi przez wspólnotę samorządową sprawami publicznymi - czyli samorząd w ścisłym sensie;

b) określoną przez przepisy prawa grupę społeczną, w której członkostwo powstaje z mocy prawa, powołaną do samodzielnego wykonywania zadań z zakresu administracji publicznej, w formach właściwych dla administracji rządowej, posiadającą organizację ustawowo ustaloną, o charakterze przedstawicielskim, kontrolowaną przez grupę, podlegającą nadzorowi ze strony Państwa, ponoszącą odpowiedzialność za swoje działania, wykonująca zadania własne i zlecone, posiadającą osobowość prawną i przysługujące jej prawo własności - czyli wspólnotę samorządową (i zarazem samorząd w sensie szerokim) ${ }^{40}$.

Obecnie istniejące izby gospodarcze jako, że są tworzone i funkcjonują na wzór stowarzyszeń, nie są - z woli tegoż samego ustawodawcy - instytucjami samorządowymi. Jak stwierdził Robert Kmieciak, izby gospodarcze winny zostać wpisane w instytucjonalny system administracji publicznej. Powinny uzyskać status związku publicznoprawnego, który działałby w imieniu Państwa na rzecz całej społeczności osób prowadzących działalność gospodarczą. Można wręcz dodać, iż izby samorządu przemysłowo-handlowego zasługują na to, aby ustawodawca wreszcie nadał im osobowość publicznoprawną i zaczął je tworzyć w drodze ustawodawczej ${ }^{41}$.

\footnotetext{
${ }^{37}$ Por. http://www.uprp.pl/ (dostęp 4.08.2011); rozporządzenie z dnia 26 lutego 2008 r. ws. oplat zwiqzanych z ochronq wynalazków, Dz. U. 2008, Nr 41, poz. 241.

${ }^{38}$ Por. http://www.proinno-europe.eu/inno-metrics/page/innovation-union-scoreboard-2010 (dostęp 5.08.2011); T. Bal-Woźniak, Dylematy ksztaltowania innowacyjności gospodarki Polski, w: Nowa ekonomia a spoteczeństwo, t. 2, red. S. Partycki, Lublin 2006, s. 324; S. Motyka, Pomiar innowacyjności przedsiębiorstwa, materiały XIV Konferencji..., s. 160 .

${ }^{39}$ Dz. U. 1989, Nr 35, poz. 195 ze zm.

40 Takie ujęcie wspólnoty samorządowej zasugerowałem w internetowym podręczniku do historii administracji (http://pl.wikibooks.org/wiki/Wikibooks). Por. też rozważania na temat istoty samorządu na gruncie politologicznym: Z. Matusewicz, Samorzqd terytorialny jako standard wspótczesnej demokracji w Europie, w: Demokracja w Polsce $i$ w świecie, red. S. Zyborowicz, Toruń 2009, s. 36.

${ }^{41}$ Por. R. Kmieciak, Perspektywy rozwoju samorzadu gospodarczego w Polsce jako podmiotu administracji publicznej, „Przegląd Politologiczny” 2008, nr 3, s. 100; idem, Formy organizacyjne samorzadu w III Rzeczypospolitej,
} 
Należy zadać sobie pytanie, czy przykładowo istnieją formalne przeszkody przed przekazaniem instytucjom samorządu gospodarczego zadań agend rządowych odpowiedzialnych za wdrażanie projektów innowacyjnych. Powstaje też pytanie, czy istnieje takowa konieczność i czy taki zabieg byłby opłacalny dla budżetu i kieszeni podatników. Ważkim pytaniem jest, czy nie byłaby to zmiana jedynie formalna, jednej biurokracji na drugą. Wtedy mielibyśmy do czynienia z owszem reforma, ale struktury, a nie formy czy filozofii działania danego wycinka administracji publicznej ${ }^{42}$.

Z punktu widzenia Kodeksu postępowania administracyjnego i dla przeciętnego obywatela nie ma bowiem żadnej różnicy czy decyzję administracyjną wydaje biurokracja samorządowa, czy rządowa. Być może, gdyby decyzje indywidualne byłyby wydawane przez samorząd gospodarczy w miejsce agencji rządowych, to poczucie przestrzegania prawa wśród osób zajmujących się działalnością gospodarczą wzrosłoby. Na pewno, gdy w miejsce - nazwijmy to wedle słynnego powiedzenia Jean Paula Sartre a - „obcej”, ,,innej”, „odległej” instytucji, wejdzie izba gospodarcza, to wielu przedsiębiorców też nie będzie się z nią utożsamiać, mimo iż teoretycznie byłaby to ,ich izba”. Pojawi się wówczas naturalny problem legitymizacji takiego samorządu ${ }^{43}$. Wtedy jednak pozostanie przynajmniej nadzieja, ale nie, że administracja samorządowa będzie bliższa obywatelowi i przez to przyjaźniejsza, lecz, że istnieć będzie nad nią administracja rządowa, która ją nadzoruje i do której w razie potrzeby można występować o interwencję.

W przypadku szerokiej decentralizacji zadań Państwa na rzecz samorządu gospodarczego, raczej nie należałoby się obawiać wzrostu poziomu nadużyć budżetowych i korupcji. Sądzić można zreszta, iż w przypadku powtarzającego się naruszania prawa łatwiej byłoby zawiesić organy samorządowej izby gospodarczej niż agencji rządowej. Zapewne, nie doszłoby też do nagłego wzrostu jakości obsługi obywatela, a usługi administracyjne świadczone przez instytucje samorządowe nie różniłyby się niczym od uprzednio wykonywanych przez biurokrację rządową. Nie jest nawet pewne, czy powstrzymałoby to rozrost biurokracji, gdyż znaczny wzrost zatrudnienia urzędników obserwuje się właśnie w strukturach samorządowych ${ }^{44}$. Problemem byłby również koszt takiej reformy tym bardziej, iż z reguły wdrożenie zmian w administracji publicznej prowadzi na wstępie do zwiększenia wydatków, a nie do ich zmniejszenia ${ }^{45}$.

Idąc dalej, można pokusić się o postawienie pytania, skoro samorząd wykonuje administrację publiczną w oparciu o obowiązujące prawo, to dlaczego nie stanowi przepisów, które potem sam musi stosować wobec swoich członków. Czy nie powinno być tak, że samorządowcy powinni tworzyć prawo, dotyczące samorządów? Czy zamiast utrzymywania obecnego modelu procesu legislacyjnego, nie należałoby wprowadzić do Senatu przedstawicieli samorządów?

w: Polska w XX wieku. Politologiczna charakterystyka dokonań i perspektywy rozwoju, red. R. Kmieciak, Poznań 2000, s. 198; idem, Rola samorzq̨u gospodarczego w ksztaltowaniu środowiska spolecznego przedsiębiorców, w: Nowa ekonomia..., s. 255; iddem, Samorzqd gospodarczy w Polsce. Rozważania na temat modelu ustrojowego, Poznań 2004, s. 215.

${ }^{42}$ Por. R. Sowiński, Reforma administracji publicznej - sukces czy porażka? (rozważania metodologiczne nad reforma), w: Adaptacja przez transformacje, red. Z. Drozdowicz, Z. W. Puślecki, Poznań 2001, s. 229.

${ }^{43}$ Por. A. Szczuciński, Demokratyczna transformacja $w$ społecznościach lokalnych, w: Adaptacja przez transformacje, red. Z. Drozdowicz, Z. W. Puślecki, Poznań 2001, s. 243.

${ }^{44}$ Por. A. Dunajska, W lubelskich urzędach przybywa pracowników, „Kurier Lubelski” 2011.05.08 (http://www.kurierlubelski.pl); J. Szydłowski, Większe wydatki na administrację, więcej urzędników, „Dziennik Wschodni” 2011.02.10 (http://www.dziennikwschodni.pl).

${ }^{45}$ Por. J. Szreniawski, Wstęp do nauki administracji, Lublin 2004, s. 118. 
Skoro doświadczenie obecnych izb gospodarczych pokazuje, iż nie ma szansy na modernizację prawa z pomocą nawet przychylnych środowisku izbowemu parlamentarzystów, to może należałoby wprowadzić przedstawicieli samorządu do Senatu? ${ }^{46}$ Zdzisław W. Puślecki i Maciej Walkowski celnie przecież stwierdzili, iż charakter procesu innowacyjnego powoduje konieczność dostosowania nie tylko standardów jego pomiaru, ale także prawa ${ }^{47}$.

Czytelnik może więc zapytać, po co więc nauka forsuje ideę samorządu gospodarczego, jeśli biurokracja samorządowa może w perspektywie niewiele różnić się od rządowej. Dzieje się tak z bardzo prostego powodu: w polskich realiach izby samorządu gospodarczego sprawdziły się lepiej niż rządowa biurokracja. Tak, jak mało który badacz samorządu terytorialnego będzie postulował wprowadzenie gmin jednowioskowych, tak wielu teoretyków samorządu gospodarczego będzie krytykowało anglosaski model polskich izb gospodarczych. Zaś to, że izby samorządu gospodarczego (w obecnym czasie tylko izby rolnicze) nie przejawiają żywszej działalności nie jest do końca wynikiem ich zaniedbań lecz tego, że ustawodawca nie przekazuje im zadań i środków, a zamiast tego i ich kosztem rozbudowuje agendy rządowe. Dlatego celem naukowców jest - jak to ujął Gerard Labuda - cierpliwe i oględne przekonywanie społecznych partnerów o konieczności zrezygnowania z przeżytych form egzystencji, a zatem przekonywanie o konieczności wprowadzenia zmian ${ }^{48}$.

Izby samorządu gospodarczego mają jeszcze tą przewagę nad izbami samorządu zawodowego, iż - poza izbami rzemieślniczymi - nie decydują w takim zakresie o kształceniu kandydatów na swoich członków, nie decydują o dopuszczeniu ich do wykonywania działalności, nie prowadzą nadzoru nad należytym wykonywaniem działalności (gospodarczej, rolniczej, rzemieślniczej), ani sądownictwa dyscyplinarnego. Odpada w ich przypadku jeden z kontrowersyjnych punktów ich oceny, a pomimo to nadal zachowują rację bytu ${ }^{49}$. Jednakże $\mathrm{w}$ trakcie tworzenia infrastruktury gospodarki rynkowej w Polsce, izb tych zabrakło ${ }^{50}$.

Samorząd gospodarczy pozwala w większym stopniu na instytucjonalizację polityki organizacji biznesowych, jako grup interesu ${ }^{51}$. Daje szansę zamiany obecnego korupcjogennego lobbingu, na działania efektywniejsze i bardziej przejrzyste. Przynajmniej zaś należy zinstytucjonalizować udział izb gospodarczych w pracach ustawodawczych rządu i komisji parlamentarnych tak, by ograniczyć chory mechanizm wyścigu o dostęp do pilnie strzė̇onej informacji o ksztalcie tworzonego prawa ${ }^{52}$. Obecnie bowiem nie jest przestrzegany wypracowany na poziomie brukselskim Kodeks postępowania dla konsultantów spraw publicznych (Voluntary code of conduct for public affairs consultants $)^{53}$.

46 Por. wypowiedzi uczestników konferencji naukowej „Czy w Polsce potrzebny jest samorząd gospodarczy i zawodowy? Spór o miejsce korporacji reprezentujących przedsiębiorców i profesje zaufania publicznego w państwie demokratycznym" - Poznań 27.05.2011 (materiały organizatorów).

47 Z. W. Puślecki, M. Walkowski, Innowacje i zatrudnienie w polityce wzrostu konkurencyjności Unii Europejskiej, Warszawa 2010, s. 18.

48 G. Labuda, Z rozważań nad kultura politycznq narodu w aspekcie historycznym, w: Przeszłość odległa i bliska. Marcelemu Kosmanowi w sześćdziesiata rocznicę urodzin, red. K. Robakowski i inni, Poznań 2000, s. 280.

49 Por. R. Kmieciak, Samorzqd zawodowy w strukturze administracyjnej państwa, w: Z badań nad samorzqdem zawodowym w Polsce, red. R. Kmieciak, Poznań 2010, s. 31.

50 Por. W. Sokół, Problemy legitymizacji w okresie transformacji ustrojowej, w: Kierunki ewolucji systemu politycznego Rzeczypospolitej Polskiej, red. M. Żmigrodzki, Lublin 1997, s. 88.

51 Por. R. Herbut, Interes polityczny - proces instytucjonalizacji polityki grup interesu oraz jej modele, w: Wprowadzenie do nauki o państwie i polityce, red. B. Szmulik, M. Żmigrodzki, Lublin 2007, s. 379.

52 G. Kopańska i inni, Raport z realizacji projektu Monitoring procesu stanowienia prawa w 2007 roku, Warszawa 2008, s. 22 (materiały Fundacji Batorego).

${ }^{53}$ Por. J. Supernat, Lobbing w procesach decyzyjnych organów władzy publicznej, w: Jakość administracji publicznej, Księga konferencyjna dedykowana Profesorowi Marcinowi Jełowickiemu, Międzynarodowa konferencja 
Można zatem zaryzykować twierdzenie, iż prawo ustrojowe na obszarze samorządu gospodarczego nie spełnia swej funkcji dynamizacyjnej. Nie promuje zmian na obszarze życia gospodarczego, które wyrażałyby dążenia i interesy przedsiębiorców. Nie wprowadza nowych instytucji prawnych, zaspokajających potrzeby osób prowadzących działalność gospodarczą. Zaś funkcje kontrolna, regulacyjna i represyjna posiadają przewagę nad funkcją innowacyjną ${ }^{54}$. Zastrzec wypada, iż pod pojęciem „funkcji” - za Piotrem Winczorkiem - rozumiem „skutek” i „rezultat”; zdając sobie sprawę z ogólnej krytyki rozważań o funkcjach prawa zaprezentowanej przez Iwonę Bogucką ${ }^{55}$. Powyższa ocena wynika też z pozytywnego nastawienia do idei samorządu gospodarczego, popartego znajomością faktów historycznych. Po części jest to też podejście relatywne, gdyż ujmuje „funkcję” prawa z punktu widzenia jednej grupy społecznej - przedsiębiorców i to przede wszystkim małych i średnich. Funkcja modernizacyjna prawa będzie więc w tym przypadku polegała na wywoływaniu skutków prawnych, pozytywnie ocenianych przez pryzmat koncepcji samorządowych ${ }^{56}$.

Paradoksalnie jedyną racją istnienia wielu obecnych izb jest wykorzystanie środków unijnych, jako instytucji otoczenia biznesu. Gdyby bowiem nie było izb gospodarczych, to nie istniałoby tyle ośrodków, które mogłyby wykorzystać omawiane fundusze i zrealizować ogłaszane konkursy (przykładowo: działanie 5.2 w Programie Innowacyjna Gospodarka; poddziałania 2.1.2 oraz 5.5.2 w Programie Operacyjnym Kapitał Ludzki; działania 1.4 i 1.6 Wielkopolskiego Regionalnego Programu Operacyjnego) $)^{57}$.

Odmiennie na tym tle rysuje się polityka rządów II RP, które rozporządzeniem z 15 lipca $1927 \mathrm{roku}^{58}$ wprowadziły jednolity samorząd przemysłowo-handlowy, zaś rozporządzeniem z 13 kwietnia 1939 roku o komisantach koncesjonowanych przyznały izbom prawo samodzielnego wydawania koncesji, regulujących rynek mięsny ${ }^{59}$. Można więc rzec, iż opisywany przez historyków bałagan ustawodawczy rządów pomajowych wykazywał się mimo wszystko doniosłym dorobkiem ${ }^{60}$.

Podsumowując wystarczy stwierdzić, iż ponad dwadzieścia lat kapitalizmu w Polsce przyniosło obywatelom wzmożoną reglamentację działalności gospodarczej i nie przywróciło samorządu gospodarczego, który mógłby stanowić tamę przeciwko tego typu negatywnym praktykom $^{61}$. Natomiast modernizacja i innowacja kojarzy się zapewne przedsiębiorcom nie z samorządem gospodarczym, ale z remontem i ulgą podatkową na zakup nowych techno$\log$ ii $^{62}$.

naukowa Cedzyna k. Kielc 24-26 września 2004 r., red. J. Łukasiewicz, Rzeszów 2004, s. 432 (http://www.supernat.pl) oraz materiały Alliance for Lobbying Transparency and Ethics Regulation ALTER-EU, http://www.alter-eu.org/about-lobbying-transparency (dostęp 6.08.2011).

${ }^{54}$ Por. T. Chauvin, T. Stawecki, P. Winczorek, Wstęp do prawoznawstwa, Warszawa 2009, s. 125; A. Korybski, L. Leszczyński, A. Pieniążek, Wstęp do prawoznawstwa, Lublin 2007, s. 47.

${ }_{55}$ Por. I. Bogucka, Funkcje prawa. Analiza pojęcia, Kraków 2000 (monografia w bazie LEX).

${ }^{56}$ Por. też na gruncie prawa pracy M. Skapsski, Ochronna funkcja prawa pracy w gospodarce rynkowej, Kraków 2006 (monografia w bazie LEX).

${ }^{57} \mathrm{http}: / /$ www.efs.gov.pl (dostęp 6.08.2011).

58 Dz. U. 1927, Nr 67, poz. 591.

${ }^{59}$ Dz. U. 1939, Nr 47, poz. 298.

${ }^{60}$ M. Sioma, Stawoj Felicjan Składkowski (1885-1962). Żolnierz i polityk, Lublin 2005, s. 353.

${ }^{61}$ Por. M. Etel, Regulowana działalność gospodarcza a zasada wolności gospodarczej, „Państwo i Prawo” 2007, nr 2, s. 41; C. Kosikowski, Nowe regulacje prawne w zakresie swobody działalności gospodarczej, „Państwo i Prawo" 2010, z. 10, s. 12.

${ }^{62}$ Por. art. 18b ustawy z dnia 15 lutego 1992 r. o podatku dochodowym od osób prawnych, Dz. U. 2011, Nr 74, poz. 397. 


\section{Summary}

\section{The innovativeness of the chambers of commerce against the background of a modernizing function of law}

On the basis of extensive sources, the author discusses the meeting point of three phenomena: innovativeness, economic self-governing bodies and the modernizing function of the law. Initially, he analyzes the meaning of the words 'innovation' and 'modernization'. The issue of innovation and innovativeness is described with reference to Joseph Schumpeter. New notions are indicated, that have emerged in academic language: innovative competence, innovative potential, innovative environment, etc. The innovative activity of modern chambers of commerce in Poland is criticized. An attempt is made to draft an ideal model of an innovation incubator. The author identifies the sources of poor development of business environment institutions, as chambers of commerce are defined, as lying in their legal organization, which is faulty in his opinion. As he emphasizes the idea of self-government (differentiating between 'self-government' and a 'self-governing community') he raises the issue of whether it is feasible to vest the tasks of the central administration in economic self-governing bodies. 